\title{
PENGARUH MOTIVASI BELAJAR, PERHATIAN ORANG TUA, DAN KEBUGARAN JASMANI TERHADAP HASIL BELAJAR PENDIDIKAN JASMANI OLAHRAGA DAN KESEHATAN
}

\author{
Anggun Permata Sari, Umar, Khairuddin \\ anggunpesari@g.mail.com, umarkepel@fik.unp.ac.id, khairuddin.ai@gmail.com \\ Program Studi Pendidikan Olahaga (S2) \\ Fakultas Ilmu Keolahragaan \\ Universitas Negeri Padang
}

\begin{abstract}
Problems in students SMP N Bukik Barisan shows the learning result of the students towards Physical Sports And Health Education is still below average. The learning result of students at SMP N Bukik Barisan affected by many factors, which are influenced by the study motivation and parens attention, and also the physical fitness. The purpose of this research is to find out the direct and indirect effect between variation of learning motivation, parental care, and the physical fitness towards the learning result of Physical Sports And Health Education.

The research method is quantitative approach path analysis. The population are all the students at SMP N 1 Bukik Barisan and all the students at SMP N 3 Bukik Barisan of the year 2015/2016 which are in total of 129 students. The sampling method is done by using Proportional Stratified Random Sampling, with 91 students as the sample. The data collected by using the questionnaire for study motivation and parents attention, physical fitness test for physical fitness and the test result of the semester II for the learning result of Physical Sports And Health Education.

The results of data analysis shows that : (1) The study motivation directly effect towards the learning result of Physical Sports And Health Education about $15 \%$. (2) The parents attention didnt directly effect to the learning result of Physical Sport And Health Education. (3) The physical fitness directly effect towards the learning result of Physical Sports And Health Education about 62,1\%. (4) The study motivation and physical fitness indirectly effect towards the result of Physical Sports And Health Education about 19,2\%. (5) Parents attention and physical fitness didnt indirectly effect toward the learning result of Physical Sports And Health Education. (6) Parents attention and study motivation indirectly influenced towards the learning result of Physical Sports And Health Education about 16,9\%.
\end{abstract}

Keywords; Study Motivation, Parents Attention, Physical Fitness, Learning Result of Physical and Healt Education 


\section{PENDAHULUAN}

Pendidikan Jasmani Olahraga dan Kesehatan (Penjasorkes) adalah mata pelajaran yang membekali siswa dengan pengetahuan tentang gerak jasmani dalam olahraga serta faktor kesehatan yang mempengaruhinya, keterampilan dalam melakukan gerak jasmani dalam berolahraga dan menjaga kesehatannya, serta sikap perilaku yang dituntut dalam berolahraga dan menjaga kesehatan sebagai suatu kesatuan yang utuh, sehingga terbentuk peserta didik yang sadar kebugaran jasmani, sadar olahraga dan sadar kesehatan. Penjasorkes merupakan salah satu mata pelajaran yang termasuk dalam Kurikulum Tingkat Satuan Pendidikan (KTSP).

Proses pembelajaran Penjasorkes di samping mengajarkan keterampilan gerak juga mengajarkan nilai-nilai sportivitas, kejujuran, disiplin dan kerjasama serta tanggung jawab sehingga siswa dapat terbentuk secara fisik dan mental.

Berdasarkan observasi awal di SMP Negeri 1 Kecamatan Bukik Barisan Kabupaten Lima Puluh Kota pada tanggal 4 Januari 2016 diperoleh data hasil belajar semester I siswa pada mata pelajaran Penjasorkes masih rendah. Siswa yang tidak tuntas rata-rata 58\% untuk setiap kelas. Sedangkan di SMP Negeri 3 Kecamatan Bukik Barisan, siswa yang tidak tuntas rata-rata 52\% untuk setiap kelas.

Kriteria kentuntasan Minimal (KKM) yang ditetapkan oleh SMP Negeri 1 Kecamatan Bukik Barisan dan SMP Negeri 3 Kecamatan Bukik Barisan pada mata pelajaran Penjasorkes adalah 75.

Menurut Dimyati (2009:3), "hasil belajar merupakan hasil dari suatu interaksi tindak belajar dan tindak mengajar. Dari sisi guru, tindak mengajar diakhiri dengan proses evaluasi hasil belajar. Dari sisi siswa, hasil belajar merupakan berakhirnya penggal dan puncak proses belajar". Lebih tegas dan rinci hasil belajar siswa dipengaruhi oleh banyak faktor baik faktor internal maupun faktor eksternal. Menurut Djaali (2012:101) “faktor-faktor yang mempengaruhi belajar, yaitu faktor yang mempengaruhi pencapaian hasil belajar berasal dari dalam diri (faktor internal) dan ada dari luar dirinya (faktor eksternal). Faktor internal meliputi motivasi, sikap, minat, intelegensi, kebiasaan belajar, konsep diri. Faktor eksternal meliputi guru, orang tua, sarana dan prasarana pembelajaran, kurikulum sekolah. 
Berdasarkan hasil pengamatan lapangan dan wawancara penulis dengan guru Penjasorkes di SMP Negeri Kecamatan Bukik Barisan permasalahan yang terjadi khususnya terkait dengan kebugaran jasmani siswa saat ini masih sangat memprihatinkan. Hal ini terlihat dengan banyaknya anak yang mengalami kelelahan yang berlebihan usai melakukan aktivitas pembelajaran Penjasorkes di sekolah, sering mengantuk di dalam kelas saat proses pembelajaran akademik, sering terkena berbagai penyakit, seperti pingsan saat upacara bendera, demam, penyakit pencernaan, serta penyakit kurang gerak yang menyebabkan terjadinya penurunan daya tahan tubuh.

Mengingat banyaknya faktor yang menentukan keberhasilan belajar siswa fokus kajian dalam penelitian ini, yang diduga kuat berpengaruh terhadap hasil belajar siswa yang belajar Penjasorkes di SMP Negeri Kecamatan Bukik Barisan adalah motivasi belajar dan kebugaran jasmani sebagai faktor internal dan perhatian orang tua sebagai faktor eksternal.

Maslow (1993:29) menjelaskan bahwa keinginan yang disadari atau perilaku yang bermotivasi mempunyai keunikan yang berfungsi sebagai penyalur untuk mengungapkan tujuan-tujuan yang lain. Hal ini lebih ditegaskan oleh Maslow (1993:31) bahwa manusia tidak pernah puas kecuali secara relatif dan keinginan manusia tidak akan muncul apabila keinginan yang sebelumnya belum terpenuhi. Apabila keinginan telah terpenuhi, maka akan muncul keinginan yang lainnya, begitu seterusnya.

Menurut Gelona (2011:42), "has found that individuals have multiple potential sources of motivatio", yang berarti individu memiliki beberapa sumber potensi motivasi. Oleh karena itu motivasi memang bisa dianggap sebagai bahan utama untuk mengejar keberhasilan tujuan dan untuk mencapai hasil yang diinginkan dan kesejahteraan.

Menurut Silalahi (2010:173) perilaku orang tua dapat mempengaruhi kepribadian anak, bahkan pada awal kehidupan. Sedangkan menurut Dalyono (2007:59) "faktor orang tua sangat besar pengaruhnya terhadap keberhasilan anaknya dalam belajar yaitu : besar kecilnya perhatian dan bimbingan orang tua, tinggi rendahnya pendidikan orang tua, besar kecilnya penghasilan, dan lain-lain”. 
Nashori (2005:51) menjelaskan hal yang termasuk perhatian orang tua dalam mendidik anak adalah a) menemani atau mendampingi anak saat belajar, b) memberi pengarahan, peringatan, dan melakukan kontrol atas aktivitas anak, c) memberi dukungan kepada anak, d) memberi penghargaan terhadap anak, e) menjadi teladan bagi anak-anak, dan f) memberi perlakuan yang adil terhadap anak laki-laki dan anak perempuan.

Kebugaran jasmani merupakan sebuah tuntutan dalam hidup agar lebih sehat dan mampu beraktifitas secara produktif. Menurut Getchell (1979:8) "kebugaran jasmani merupakan kapasitas untuk melaksanakan kegiatan sehari-hari (bekerja dan bermain) tanpa kelelahan yang berlebihan dan masih memiliki cadangan energi yang cukupuntuk keadaan darurat".

Setiap orang membutuhkan kebugaran jasmani yang baik agar dapat melaksanakan pekerjaan dengan efektif dan efisien tanpa mengalami kelelahan yang berarti. Secara umum yang dimaksud "kebugaran jasmani adalah kebugaran fisik (phycal fitness), yakni kemampuan seseorang melakukan kerja sehari-hari secara efisien tanpa timbul kelelahan yang berlebihan sehingga masih dapat menikmati waktu luangnya".

Menurut Ismaryati (2008:40) adapun fungsi kebugaran jasmani dapat dikelompokkan menjadi dua yaitu fungsi yang bersifat umum dan khusus.

"Fungsi umum dari kebugaran jasmani adalah untuk mengembangkan kekuatan, kemampuan, kesanggupan, daya kreasi, dan daya tahan setiap manusia yang berguna untuk mempertinggi daya kerja. Selain itu fungsi khusus dari kebugaran jasmani adalah sesuai dengan kekhususan masing-masing yang dibedakan menjadi tiga golongan yaitu golongan yang berdasarkan pekerjaan seperti atlet, pelajar dan mahasiswa".

Selain itu, kondisi jasmani yang bugar/segar akan mempengaruhi daya tahan siswa dalam menjalankan aktivitasnya dan juga akan mempengaruhi kondisi siswa dalam prestasi belajar, Murdiyanto (2015:4). 


\section{METODE PENELITIAN}

Metode yang digunakan dalam penelitian ini adalah metode kuantitatif dengan menggunakan pendekatan Path Analysis yaitu menggunakan persamaan struktural yang melihat kausalitas dimensi pengaruh Motivasi Belajar $\left(\mathrm{X}_{1}\right)$ Perhatian Orang Tua $\left(\mathrm{X}_{2}\right)$ terhadap Hasil Belajar Penjasorkes (Y) melalui Kebugaran Jasmani $\left(\mathrm{X}_{3}\right)$.

Riduwan (2012:115) menjelaskan bahwa teknik analisis jalur digunakan dalam menguji besarnya sumbangan (kontribusi) yang ditunjukkan oleh koefisien jalur pada setiap diagram jalur dari hubungan kausal antara variabel $\mathrm{X}_{1}, \mathrm{X}_{2}$, dan $\mathrm{X}_{3}$ terhadap Y. Untuk lebih jelasnya dapat dilihat pada bagan desain berikut ini;

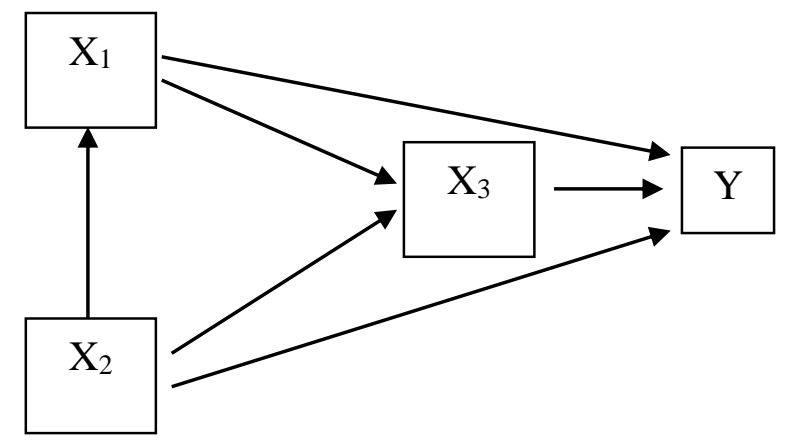

Tempat penelitian ini dilaksanakan di SMP Negeri 1 Kecamatan Bukik Barisan dan di SMP Negeri 3 Kecamatan Bukik Barisan. Sedangkan waktu penelitian dilaksanakan pada bulan April 2016.

Populasi penelitian ini adalah seluruh siswa SMP Negeri 1 Kecamatan Bukik Barisan dan seluruh siswa SMP Negeri 3 Kecamatan Bukik Barisan kelas VII dan kelas VIII yang berjumlah sebanyak 129 orang. Sampel dalam penelitian ini berjumlah 91 orang siswa yang diambil secara acak dari masing-masing kelas. Teknik penarikan sampel yang digunakan adalah dengan teknik "Proportional Stratified Random Sampling”.

Instrumen dalam penelitian berupa kuisioner dengan skala yang digunakan dalam penyebaran kuesioner/angket adalah Skala Likert untuk variabel motivasi belajar dan perhatian orang tua. Sedangkan untuk variabel kebugaran jasmani menggunakan Tes Kebugaran Jasmani Indonesia (TKJI) untuk anak yang berusia 13-15 tahun. 
Teknik pengumpulan data dalam penelitian ini dilakukan melalui penyebaran kuesioner/ angket motivasi belajar dan perhatian orang tua. Sedangkan untuk kebugaran jasmani Tes Kesegaran Jasmani Indonesia (TKJI) usia 13-15 tahun yang terdiri dari tes lari cepat (sprint 50 meter), tes angkat tubuh (pull up 60 detik), tes baring duduk (sit up 60 detik), tes loncat tegak (vertical jump), dan tes lari jauh (lari 1000 meter untuk putera dan lari 800 meter untuk puteri). Data yang telah terkumpul dianalisis dengan path analysis.

\section{HASIL PENELITIAN DAN PEMBAHASAN}

Berdasarkan hasil analisis data, diperoleh koefesien jalur yang tidak signifikan yaitu koefisien jalur perhatian orang tua terhadap kebugaran asmani dan koefisien jalur perhatian orang tua terhadap hasil belajar Penjasorkes, maka model perlu diperbaiki dengan model trimming. Model trimming adalah model yang digunakan untuk memperbaiki suatu model struktur analisis jalur dengan cara mengeluarkan variabel eksogen yang koefisiennya tidak signifikan dari model struktur, Riduwan (2012:127). Cara menggunakan model trimming yaitu menghitung ulang koefisien jalur tanpa menyertakan variabel eksogen yang koefisien jalurnya tidak signifikan.

\section{Motivasi Belajar Berpengaruh Langsung Terhadap Hasil Belajar Penjasorkes}

Dari hasil analisis diperoleh nilai t motivasi belajar sebesar 1.727, nilai koefesien jalur antara $\mathrm{X}_{1}$ terhadap $\mathrm{Y}\left(\rho \mathrm{yx}_{1}\right)=0.162$ dan nilai Sig. 0.000. Ternyata nilai Sig. < nilai probabilitas yaitu $0.000<0.05$, maka koefesien analisis jalur adalah signifikan, Artinya terdapat pengaruh langsung yang signifikan antara motivasi belajar terhadap hasil belajar Penjasorkes.

Ketekunan dalam belajar dan tugas hal yang dilakukan siswa salah satu contohnya adalah siswa tersebut dapat bekerja terus menerus dalam waktu yang lama, jika pekerjaannya dalam belajar belum selesai maka siswa tersebut tidak pernah berhenti.

Motivasi merupakan hal yang perlu diperhatikan dalam kegiatan belajar siswa termasuk dalam hubungannya dengan perhatian orang tua di rumah. Menurut Sardiman (2001:73) motivasi belajar sebagai keseluruhan daya penggerak di dalam 
diri siswa yang menimbulkan kegiatan belajar, yang menjamin kelangsungan dari kegiatan belajar dan yang memberikan arah pada kegiatan belajar, sehingga tujuan yang dikehendaki dapat dicapai.

Uno (2011:23) berpendapat bahwa "motivasi belajar adalah dorongan internal dan eksternal pada siswa-siswa yang sedang belajar untuk mengadakan perubahan tingkah laku, pada umumnya dengan beberapa indikator atau unsur yang mendukung".

Motivasi belajar lebih erat kaitannya pada penilaian kognitif (intelegensi) dibandingkan penilaian psikomotor (gerak). Untuk menciptakan motivasi belajar yang kuat, guru harus mampu memilih strategi pembelajaran yang sesuai dengan sifat pesan yang disampaikan serta kemampuan masing-masing siswa. Melalui strategi yang tepat siswa akan terdorong dan bersemangat dalam belajar. Semakin tinggi motivasi belajar siswa SMP Negeri Kecamatan Bukik Barisan maka semakin besar sumbangannya terhadap hasil belajar Penjasorkes, hal ini diperoleh dengan cara sungguh-sungguh untuk berprestasi yang tinggi.

\section{Perhatian Orang Tua Ber-pengaruh Langsung Terhadap Hasil Belajar Penjasorkes}

Dari hasil analisis diperoleh nilai t perhatian orang tua sebesar 0.271 , nilai koefesien jalur antara $\mathrm{X}_{2}$ terhadap $\mathrm{Y}\left(\rho \mathrm{yx}_{2}\right)=0.025$ dan nilai Sig. 0.087. Ternyata nilai Sig. < nilai probabilitas yaitu $0.087>0.05$, maka koefesien analisis jalur adalah tidak signifikan, Artinya tidak terdapat pengaruh langsung yang signifikan antara perhatian orang tua terhadap hasil belajar Penjasorkes.

Perhatian orang tua dalam hal pendidikan anaknya adalah kesadaran orang tua (kandung, tiri, maupun angkat) atau wali untuk memusatkan aktivitasnya terhadap pendidikan anaknya. Faktor keluarga sangat berpengaruh terhadap keberhasilan anak dalam belajar. Hal ini sesuai dengan pendapat Dalyono (2007:59) “faktor orang tua sangat besar pengaruhnya terhadap keberhasilan anaknya dalam belajar yaitu : besar kecilnya perhatian dan bimbingan orang tua, tinggi rendahnya pendidikan orang tua, besar kecilnya penghasilan, dan lain-lain”.

Orang tua yang secara sadar mendidik anak-anaknya akan selalu dituntun oleh tujuan pendidikan, yakni kearah anak dapat mandiri, ke arah satu kepribadian 
yang utama. Dengan demikian pengaruh orang tua terhadap pendidikan anaknya sangat besar. (Hasbullah, 2012:22). Ubaedy (2009:37) menyatakan bahwa: keterlibatan orang tua dalam proses akademik anak ternyata sangat membantu proses perkembangannya di sekolah.

Beranjak dari temuan penelitian tersebut dapat diambil benang merah bahwa perhatian orang tua tidak dapat memberikan pengaruh yang signifikan terhadap hasil belajar Penjasorkes, dengan kata lain terdapat ketidak sesuaian hasil temuan penelitian dengan teori dan kerangka berpikir.

Faktor lain tidak diterimanya hipotesis ini adalah perhatian orang tua lebih terfokus pada aspek kognitif. Selain itu, masih rendahnya pengawasan orang tua siswa SMP Negeri Kecamatan Bukik Barisan terhadap pembelajaran Penjasorkes. Pengawasan orang tua berarti mengontrol semua kegiatan atau aktivitas yang dilakukan oleh anak baik secara langsung maupun tidak langsung.

\section{Kebugaran Jasmani Ber-pengaruh Langsung Terhadap Hasil Belajar Penjasorkes}

Dari hasil analisis diperoleh nilai t kebugaran jasmani sebesar 7.546, nilai koefesien jalur antara $\mathrm{X}_{3}$ terhadap $\mathrm{Y}\left(\rho \mathrm{yx}_{3}\right)=0.620$ dan nilai Sig. 0.000. Ternyata nilai Sig. < nilai probabilitas yaitu $0.000<0.05$, maka koefesien analisis jalur adalah signifikan, Artinya terdapat pengaruh langsung yang signifikan antara kebugaran jasmani terhadap hasil belajar Penjasorkes.

Temuan penelitian menunjukkan bahwa kebugaran jasmani memiliki pengaruh langsung yang signifikan terhadap hasil belajar Penjasorkes siswa SMP Negeri Kecamatan Bukik Barisan. Hal ini sesuai dengan pendapat Ismaryati (2008:40) yang menyatakan fungsi dari kebugaran jasmani salah satunya adalah pekerjaan seperti pelajar untuk meningkatkan prestasi belajar.

Kebugaran jasmani yang sangat baik akan dapat memberikan sumbangan pengaruh yang besar terhadap hasil belajar penjasorkes, begitupun sebaliknya. Untuk itu, siswa SMP Negeri Kecamatan Bukik Barisan perlu meningkatkan kebugaran jasmaninya melalui latihan-latihan atau berolahraga yang terprogram. 


\section{Motivasi Belajar Berpengaruh Terhadap Hasil Belajar Pen-jasorkes Melalui Kebugaran Jasmani}

Pengaruh tidak langsung motivasi belajar dan kebugaran jasmani terhadap hasil belajar Penjasorkes merupakan nilai perkalian antara pengaruh langsung motivasi belajar terhadap kebugaran jasmani atau $\left(\rho \mathrm{x}_{1} \mathrm{x}_{3}\right)$ dengan pengaruh langsung kebugaran jasmani terhadap hasil belajar penjasorkes atau ( $\left.\rho \mathrm{yx}_{3}\right)$. Dimana nilai $\rho \mathrm{x}_{1} \mathrm{x}_{3}=0.310$ dan $\rho \mathrm{yx}_{3}=0.620$, dengan demikian $\rho \mathrm{x}_{1} \mathrm{x}_{3} \cdot \rho \mathrm{yx}_{3}=0.310 \times 0.620$ $=0.192$. Maka dapat dikatakan besarnya pengaruh tidak langsung antara motivasi belajar dan kebugaran jasmani terhadap hasil belajar Penjaorkes yaitu sebesar 0.192 atau $19.2 \%$ (signifikan).

Seseorang yang mempunyai motivasi belajar yang tinggi, ditunjang dengan kebugaran jasmani yang baik, sehingga dengan sungguh-sungguh untuk mengikuti pembelajaran Penjasorkes dan menguasai materi yang telah diajarkan, secara tidak langsung motivasi belajar memberikan pengaruh terhadap hasil belajar Penjasorkes. Semakin tinggi motivasi belajar dan semakin baik kebugaran jasmani siswa maka semakin baik hasil belajar Siswa SMP Negeri Kecamatan Bukik Barisan.

\section{Perhatian Orang Tua Berpengaruh Terhadap Hasil Belajar Penjasorkes Melalui Kebugaran Jasmani}

Dari hasil analisis koefisien jalur, perhatian orang tua terhadap kebugaran jasmani tidak memiliki pengaruh langsung dimana nilai $\mathrm{t}$ perhatian orang tua $=$ 0.723 dengan nilai Sig. $=0.472$ dan nilai koefesien jalur antara $\mathrm{X}_{2}$ terhadap $\mathrm{X}_{3}$ $\left(\rho_{2} \mathrm{x}_{3}\right)=0.085$. Ternyata nilai $\quad$ Sig. $<$ nilai probabilitas yaitu $0.472>0.05$, maka koefesien analisis jalur adalah tidak signifikan, Artinya tidak terdapat pengaruh langsung.

Beranjak dari penelitian tersebut dapat diambil benang merah bahwa perhatian orang tua tidak memiliki pengaruh tidak langsung terhadap hasil belajar Penjasorkes melalui kebugaran jasmani. Secara umum, perhatian orang tua tidak terlalu fokus terhadap aktivitas yang dilakukan oleh seorang anaknya. Sehingga dalam aktivitas sehari-hari anak bebas melakukan kegiatan, baik aktivitas yang 
sangat berhubungan dengan aspek psikomotorik maupun aktivitas yang berhubungan dengan aspek afektif dan kognitif.

\section{Perhatian Orang Tua Berpengaruh Terhadap Hasil Belajar Penjasorkes Melalui Motivasi Belajar}

Pengaruh tidak langsung perhatian orang tua dan motivasi belajar terhadap hasil belajar Penjasorkes merupakan nilai perkalian antara pengaruh langsung perhatian orang tua terhadap motivasi belajar atau $\left(\rho \mathrm{x}_{2} \mathrm{x}_{1}\right)$ dengan pengaruh langsung motivasi belajar terhadap hasil belajar Penjasorkes atau $\left(\rho \mathrm{yx}_{1}\right)$. Dimana nilai $\rho \mathrm{x}_{2} \mathrm{x}_{1}=0.461$ dan $\rho \mathrm{yx}_{1}=0.162$ dengan demikian $\rho \mathrm{x}_{2} \mathrm{x}_{1}$. $\rho \mathrm{yx}_{1}=0.461 \mathrm{x}_{0} 0.162$ $=0.175$. Maka dapat dikatakan besarnya pengaruh tidak langsung antara perhatian orang tua dan motivasi belajar terhadap hasil belajar Penjaorkes yaitu 0.175 atau $17.5 \%$ (signifikan).

Setelah dilakukan analisis dengan model trimming nilai $\rho \mathrm{x}_{2} \mathrm{x}_{1}=0.461 \mathrm{dan}$ nilai $\rho \mathrm{yx}_{1}=0.150$, dengan demikian $\rho \mathrm{x}_{2} \mathrm{x}_{1} \cdot \rho \mathrm{yx}_{1}=0.461 \times 0.150=0.169$. Maka dapat diketahui besarnya pengaruh tidak langsung perhatian orang tua dan motivasi belajar terhadap hasil belajar adalah sebesar 0.169 atau 16.9\% (signifikan).

Beranjak dari temuan penelitian tersebut dapat di lihat bahwa hasil belajar Penjasorkes siswa SMP Negeri Kecamatan Bukik Barisan secara tidak langsung dipengaruhi oleh perhatian orang tua melalui motivasi belajar. Hal ni seirama dengan pendapat Iftikhah (2013:86) yang menyatakan bahwa perhatian orang tua mempengaruhi motivasi belajar yang akan menunjang hasil belajar anak. Hal itu disebabkan karena perhatian orang tua merupakan salah satu aspek yang dapat mempengaruhi motivasi belajar secara tidak langsung, untuk mendapatkan hasil belajar Penjasorkes yang baik seorang siswa haruslah memiliki perhatian orang tua yang bagus, sementara siswa akan memiliki motivasi belajar yang baik apabila memiliki perhatian orang tua yang bagus.

Setelah mengalami perubahan model struktural menjadi model trimming maka koefesien jalur dapat secara lengkap dituangkan dalam kerangka konseptual sebagaimana dalam gambar berikut: 


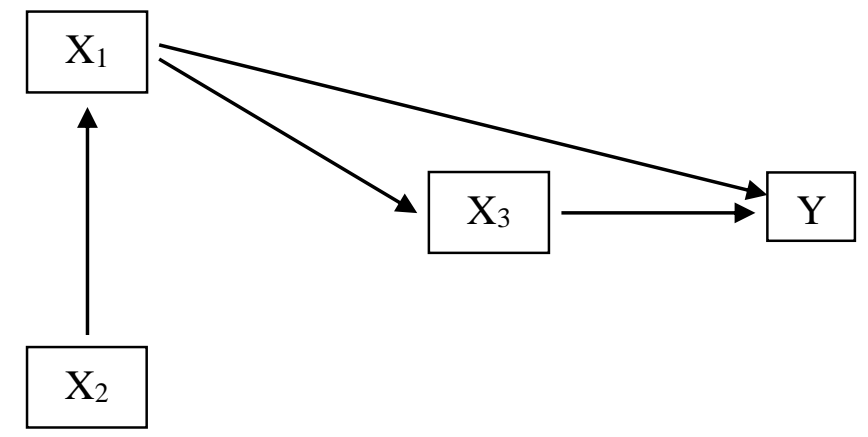

Berdasarkan rumus-rumus analisis pencarian koefisien jalur, dapat diketahui besarnya nilai koefisien jalur. Adapun nilai koefisien jalur tersebut dapat dilihat pada tabel berikut.

Tabel Sumbangan Efektif Variabel Eksogen terhadap Variabel En-dogen (Hasil Belajar Penjasorkes)

\begin{tabular}{|c|c|c|c|c|}
\hline Variabel & Koefisien Jalur & \multicolumn{3}{|c|}{ Pengaruh } \\
\cline { 3 - 5 } & Langsung & Tidak Langsung & Total \\
\hline $\begin{array}{c}\text { Motivasi Belajar } \\
\text { (X1) }\end{array}$ & 0.150 & 0.150 & 0.193 & 0.343 \\
\hline $\begin{array}{c}\text { Perhatian Orang } \\
\text { Tua (X2) }\end{array}$ & 0.000 & 0.000 & 0.169 & 0.169 \\
\hline $\begin{array}{c}\text { Kebugaran } \\
\text { Jasmani (X3) }\end{array}$ & 0.621 & 0.621 & 0.000 & 0.621 \\
\hline
\end{tabular}

\section{Kesimpulan}

Mengacu pada hasil pengujian hipotesis, maka dapat diambil kesimpulan sebagai berikut :

1. Motivasi belajar berpengaruh secara langsung terhadap hasil belajar Penjasorkes siswa SMP Negeri 1 Kecamatan Bukik Barisan dan SMP Negeri 3 Kecamatan Bukik Barisan sebesar 15\%.

2. Perhatian orang tua tidak berpengaruh secara langsung terhadap hasil belajar Penjasorkes siswa SMP 1 Negeri Kecamatan Bukik Barisan dan SMP Negeri 3 Kecamatan Bukik Barisan.

3. Kebugaran jasmani berpengaruh secara langsung terhadap hasil belajar Penjasorkes siswa SMP Negeri 1 Kecamatan Bukik Barisan dan SMP Negeri 3 Kecamatan Bukik Barisan sebesar 62.1\%. 
4. Motivasi belajar dan kebugaran jasmani berpengaruh secara tidak langsung terhadap hasil belajar Penjasorkes siswa SMP Negeri 1 Kecamatan Bukik Barisan dan SMP Negeri 3 Kecamatan Bukik Barisan sebesar 19.2\%.

5. Perhatian orang tua dan kebugaran jasmani tidak berpengaruh secara tidak langsung terhadap hasil belajar Penjasorkes siswa SMP Negeri 1 Kecamatan Bukik Barisan dan SMP Negeri 3 Kecamatan Bukik Barisan.

6. Perhatian orang tua dan motivasi belajar berpengaruh secara tidak langsung terhadap hasil belajar Penjasorkes siswa SMP Negeri 1 Kecamatan Bukik Barisan dan SMP Negeri 3 Kecamatan Bukik Barisan sebesar 16.9\%.

\section{Saran}

Berdasarkan temuan penelitian dan implikasi penelitian, maka dikemukakan saran-saran sebagai berikut:

1. Kepada siswa diharapkan untuk dapat meningkatkan motivasi belajar seperti menanamkan rasa suka terhadap belajar, tidak mudah menyerah saat menghadapi kesulitan dalam belajar, menanamkan sifat tekun dalam belajar dan meningkatkan kebugaran jasmani seperti rutin melakukan olahraga dalam upaya mencapai hasil belajar Penjasorkes yang optimal.

2. Diharapkan kepada orang tua siswa untuk tidak hanya memberikan perhatian pada pembelajaran yang kognitif saja, namun juga harus memberikan perhatian yang dapat meningkatkan kemampuan anak dalam menguasai pembelajaran Penjasorkes.

3. Kepada guru Penjasorkes diharapkan untuk dapat mengembangkan strategi pembelajaran dan meningkatkan motivasi belajar siswa.

4. Kepada Kepala Sekolah diharapkan mampu mendukung dan membina kerja sama yang baik dengan orang tua siswa maupun guru Penjasorkes dalam melengkapi fasilitas, sarana dan prasarana untuk bisa menjalani program yang telah dibuat oleh guru Penjasorkes.

5. Bagi peneliti lainnya untuk dapat melakukan penelitian lanjutan dengan mengkaji faktor-faktor lain yang mempengaruhi hasil belajar Penjasorkes

\section{DAFTAR RUJUKAN}

Dalyono. (2007). Psikologi Pendidikan. Jakarta : Rineka Cipta. 
Dimyati, dan Mujiono. (2009). Belajar dan Pembelajaran. Jakarta: DEPDIKBUD.

Djaali. (2012). Psikologi Pendidikan. Jakarta : Bumi Aksara.

Getchell, Bud. (1979). Physical Fitness: A Way Of Life $2^{\text {nd }}$ edition. Muncie: John Wiley \& Sons, Inc.

Hasbullah. (2012). Dasar-dasar Ilmu Pendidikan. Jakarta : Raja Grafindo Persada.

Iftikhah, Rizka. 2013. Pengaruh Perhatian Orang Tua Terhadap Motivasi Belajar Siswa. Jurnal. IKIP Veteran Semarang.

Ismaryati. (2008). Tes dan Pengukuran Olahraga. Surakarta: UNS Press

Maslow, Abraham H. (1993). Motivasi dan Kepribadian 1"eori Motivasi Dengan Pendekatan Hierarki Kebutuhan Manusia. Bandung : Remaja Rosdakarya Offset.

Murdiyanto, Anang. (2015). Hubungan Antara Kebugaran Jasmani Dengan Prestasi Belajar Pendidikan Jasmani Di Smp Muhammadiyah Ngadirojo. Tesis. Nusantara PGRI Kediri.

Riduwan dan Engkos Achmad Kuncoro. (2012). Cara Menggunakan dan Memakai Path Analysis (Analisis Jalur). Bandung : Alfabeta.

Sardiman, A. M. (2001). Interaksi dan Motivasi Belajar Mengajar. Jakarta: Raja Grafindon Persada.

Silalahi, K \& Meinarno E. A. (2010). Keluarga Indonesia: Aspek dan Dinamika Zaman. Jakarta: Rajawali.

Ubaedy. (2009). Cerdas Mengasuh Anak. Jakarta: Kinza Books.

Uno, Hamzah B. (2011). Teori Motivasi dan Pengukurannya: Analisis Di Bidang Pendidikan. Jakarta : Bumi Aksara. 